\title{
The Application of Process Writing in Chinese EFL Classrooms in Higher Education
}

\author{
Zhi-Qin Wang ${ }^{1}$ \\ ${ }^{1}$ School of Foreign Languages, Sichuan University, Sichuan, China \\ ${ }^{2}$ School of Foreign Languages, China West Normal University, Sichuan, China \\ Correspondence: Zhi-Qin Wang, School of Foreign Languages, China West Normal University, No. 1 Shi Da \\ Road, Nanchong 637009, Sichuan, China. Tel: 86-180-3047-2313. E-mail: wzq76@163.com
}

Received: March 11, 2014 Accepted: April 12, 2014 Online Published: May 27, 2014

doi:10.5539/ijel.v4n3p88 URL: http://dx.doi.org/10.5539/ijel.v4n3p88

\begin{abstract}
This paper aims to investigate potential advantages of process writing in Chinese EFL classrooms in higher education. A survey of questionnaires and semi-structured interviews are employed to elicit data. 150 Junior English majors and 3 writing teachers who have conducted process writing at China West Normal University (CWNU) in Sichuan, Southwest China are invited to take part in the investigation. The results show that process writing has many advantages during its three stages: the pre-writing stage (including brainstorming), the while-writing stage (involving three drafts of writing) and the post-writing stage (covering peer review, teacher feedback and final publication). It is concluded that process writing can benefit both students and their teachers, which can be regarded as an effective part of Chinese EFL classrooms in higher education. As EFL classrooms share some similar features in teaching writing, this study may have some implications for other EFL countries as well.
\end{abstract}

Keywords: process writing, Chinese EFL classrooms, higher education

\section{Introduction}

The traditional way of teaching writing in Chinese EFL Classrooms in higher education can neither cater to students' needs nor satisfy teachers themselves. The teacher always gives students a topic and asks them to write individually by duplicating the model. And then only the teacher will give feedback to students' writings. Such a traditional way of teaching writing frustrates both students and teachers. On the one hand, students are puzzled about what to write and how to write, especially when they are not quite familiar with the given topic. And they feel it very boring to "produce the similar text" (Jordan, 1997, p. 165) under the same topic. Besides, students state that it is too late to give them feedback, so that sometimes they may forget what they have written in detail. Moreover, students often complain that no apparent progress has been made in their writing abilities in spite of their time-consuming practice. On the other hand, writing teachers are usually called as "a tired dog" (Zamel, 1985, p. 79), for it often takes them a lot of time to correct all students' errors in terms of the content, structure, grammar, vocabulary, spelling and even punctuation. Although teachers have exhausted themselves to correct all kinds of mistakes each time, those similar mistakes may occur again and again in students' subsequent writings. This will make those teachers rather depressed. As neither students nor teachers are satisfied with the traditional way of teaching writing, some measures need to be taken in Chinese EFL classrooms in higher education.

Communicative Language Teaching requires the teacher to play the role of "facilitator and monitor" (Richards, 2005 , p. 4). Chew (2006) also states that teachers should be facilitators rather than purely knowledge-givers, and learners should become autonomous and responsible in their own learning (Jacobs, 1989). Process writing focuses on the process rather than on the final product, which can be beneficial to enhance students' writing abilities (White \& Arndt, 1991; Jordan, 1997; Liu \& Hansen, 2002). According to Tompkins (1990), process writing covers five stages: prewriting, drafting, revising, editing and publishing. Different from the traditional way of writing, process writing includes a sequence of activities: "the first draft $>$ peer review $>$ the second draft $>$ teacher feedback $>$ the third draft $>$ publication (Hu, 2005, p. 138). Chew (2006) suggests that activities in process writing should involve brainstorming, three drafts, peer review, and feedback. Therefore, based on the previous study, this paper puts forward that process writing includes three stages: the pre-writing 
stage, the while-writing stage and the post-writing stage, in which a sequence of activities are carried out: brainstorming $\rightarrow$ the first draft $\rightarrow$ peer review $\rightarrow$ the second draft $\rightarrow$ peer review $\rightarrow$ the third draft $\rightarrow$ teacher feedback $\rightarrow$ final publication.

With an aim to find out possible advantages of process writing in Chinese EFL classrooms in higher education, this study employs a survey of questionnaires and semi-structured interviews to investigate junior English majors and their writing teachers who have conducted process writing at China West Normal University in Sichuan, China. The results show that process writing has many potential advantages during its three stages: the pre-writing stage (including brainstorming), the while-writing stage (involving students' three drafts of writing), and the post-writing stage (covering peer review, teacher feedback and final publication). As process writing can benefit both students and teachers, it can be applied to Chinese EFL classrooms in higher education. Besides, as EFL classrooms share some common features in teaching writing, this study may also shed light on English writing courses in other EFL countries.

\section{Theoretical Basis}

In the pre-writing stage, students can brainstorm about the given topic. Brainstorming allows students "to share ideas, learn from others, and produce new ideas" (Raimes, 1987, p. 22). By means of brainstorming, students can think fast about a writing topic and share some opinions in class. Such a stage is very crucial for students, particularly when they are not quite familiar with the given topic.

In the while-writing stage, students are required to produce three drafts. Barr (1983) puts forward that multiple drafting can improve the quality of writing. This is echoed by Chew (2006), students can write to learn through different drafts. In the first drafts, students focus on the macro level of expressing their ideas. In the second drafts, students emphasize the micro level of vocabulary, grammar and spelling, etc. In the third drafts, students try their best to make perfect writings both in the content and in the form. Thus, through drafting and redrafting, reviewing and revising (Takagaki, 2003), students are expected to make progress in their writings.

The post-writing stage includes peer review, teacher feedback and final publication. Defined as responding with appreciation and positive criticism to classmates' writings, peer review is an important alternative to teacher-based forms of response in writing (Hyland, 2003). As an innovative instructional method of cooperative learning, peer review plays a prominent role in process-oriented writing (Hu, 2005). First of all, peer review can reduce teachers' workload and liberate them from stressful mental and physical labor in marking all students' papers in detail (Hyland, 2003). Secondly, peer review can provide chances for students to write to learn in the interaction between writers and readers (Chew, 2006). Thirdly, the prompt and direct peer review can benefit students a lot, particularly when they need help during their writing process (Chandrasegaran, 2002). Moreover, as a social act, peer review can promote "collaborative relationship and a sense of audience" (Grabe \& Kaplan, 1996, p. 380). What's more, peer review can reduce students' anxiety because of their equal status with each other. As a useful practice in the process of writing, peer review has been widely used in L1 writing classrooms.

In addition to peer review, the post-writing stage includes teacher feedback. Traditionally, most teacher feedback only focuses on the form rather than on the content (Sommers, 1982), which is not enough to promote students' writing ability. Therefore, in process writing, teachers are advised to give feedback to students' writings in terms of the clear idea, logical structure, appropriate diction, and rhetoric device, etc. What's more, teachers need to comment peers' review as well, especially when there are some puzzles or disagreements among students. Moreover, teachers should pick out some excellent writings for publication and note down some typical writing problems among students. By means of such feedback-related revisions, students are expected to improve their writing abilities (Ferris, 1997).

Apart from teacher feedback, the post-writing stage includes final publication. During this stage, some students will talk about their excellent writings in class. To publish students' writings is a good way to encourage their motivation (Hu, 2005), and it can also acknowledge peers' hard work and promote mutual learning among students.

It can be seen that process writing has many advantages during the pre-writing stage, the while-writing stage and the post-writing stage. As an alternative to the traditional pattern of teaching writing, process writing can be shared by both native and non-native language learners (Zamel, 1983). Therefore, process writing can be applied to Chinese EFL classrooms as well.

\section{Methodology}

\subsection{Participants}

In order to find out potential advantages of process writing in Chinese EFL classrooms in higher education, 150 
junior English majors and their 3 writing teachers who have conducted process writing at CWNU are invited to participate in this investigation. English majors aim to pass the TEM-4 (Test for English Majors - Band 4) and the TEM-8 before graduation, most of whom will become English teachers after graduation, so good writing competence is essential to those junior English majors. Three English teachers in this investigation have taught English writing for several years, and two of them have studied English teaching abroad.

\subsection{Instrument and Data Collection}

With an aim to find out how junior English majors and their writing teachers at CWNU perceive process writing, this study employs a survey of questionnaires and semi-structured interviews to learn about "the inner life of the participants" (Taylor \& Bogdan, 2001, p. 7).

First of all, a survey of questionnaires is used to investigate junior English majors at CWNU about their perceptions towards process writing. This questionnaire is designed according to Tompkins (1990), Hu (2005) and Chew (2006), which focuses on five activities in process writing, namely, brainstorming, three drafts of writing, peer review, teacher feedback and final publication. The sample questionnaire in English (see Appendix A) requires students to choose some activity (or activities) in process writing which can help them to enhance their writing abilities. At the end of the first semester, 150 questionnaires are randomly distributed to junior English majors who have experienced process writing at CWNU. Students are given clear instructions on how to complete the questionnaires before they start. All the questionnaires are finished in captive groups and then are collected successfully.

Secondly, as multiple methods and techniques can be used for developments in the ongoing investigation (Mackey \& Gass, 2005), semi-structured interviews are employed as well. 20 junior English majors who have taken part in the survey of questionnaires are invited to participate in the semi-structured interview, so that we can deepen our understanding of the questionnaire data. To help the students feel more at ease, this face-to-face interview is conducted in Chinese. The interview with each student lasts about 5 minutes, in which students are requested to talk about the reason why some activities in process writing are good to improve their writing proficiency (see Appendix B). With the consent of those junior English majors, this interview is recorded and then is transcribed and translated into English.

Thirdly, apart from students' perceptions, how their writing teachers perceive process writing is also studied. Three English teachers who have conducted process writing at CWNU are invited to participate in the semi-structured interview. This interview is carried out in English for about 30 minutes, in which three English teachers talk about which activity they like best in process writing and the reason why such an activity is beneficial in Chinese EFL classrooms in higher education (see Appendix C). With teachers' consent, this interview is also recorded and then transcribed.

\subsection{Data Analysis}

The data elicited from the 150 questionnaire responses is given a descriptive statistics analysis. First of all, all the responses in the questionnaires are categorized according to activities during those three stages of process writing. Next, the number of junior English majors reporting advantages of process writing is counted. And then, the percentage of junior English majors acknowledging advantages of process writing is also figured out (see Table 1).

After reading through transcriptions of semi-structured interviews, this study finds out some patterns relating to activities during three stages of process writing: the pre-writing stage (including brainstorming), the while-writing stage (involving three drafts of writing), and the post-writing stage (covering peer review, teacher feedback and final publication). In order to deepen our understanding of possible advantages of process writing, this paper also quotes some opinions expressed by junior English majors and their writing teachers in the face-to-face interviews (see 4.2 Results of interviews).

\section{Results}

\subsection{Results of Questionnaires}

After statistics analysis of the 150 questionnaires, the number and the percentage of students reporting advantages of process writing are presented in Table 1 . 
Table 1. Perceptions of junior English majors about process writing at CWNU ( $\mathrm{n}=150)$

\begin{tabular}{llcc}
\hline Stages of process writing & Activities & $\begin{array}{l}\text { The number of students reporting } \\
\text { advantages of process writing }\end{array}$ & The percentage \\
\hline The pre-writing stage & Brainstorming & 90 & $60 \%$ \\
The while-writing stage & $\begin{array}{l}\text { Three drafts of } \\
\text { writing }\end{array}$ & 78 & $52 \%$ \\
The post-writing stage & Peer review & 107 & $71 \%$ \\
& Teacher feedback & 96 & $64 \%$ \\
& Final publication & 87 & $58 \%$ \\
\hline
\end{tabular}

It can be see that most students acknowledge advantages of process writing, for more than $50 \%$ of students think that each activity in process writing is beneficial to improve their writing abilities. During those three stages of process writing, students like the post-writing stage most, which involves peer review, teacher feedback and final publication. Particularly, $71 \%$ of students favor peer review which is the activity they like best in process writing.

\subsection{Results of Interviews}

Most students acknowledge advantages of activities in process writing during all three stages. As for English teachers, they think highly of brainstorming during the pre-writing stage, three drafts of writing during the while-writing stage, and teacher feedback during the post-writing stage.

\subsubsection{Advantages of the Pre-Writing Stage}

More than half of students state that they can benefit from the pre-writing stage by means of brainstorming.

S1: I like brainstorming very much. It helps me to learn some new information from my classmates, so I can have more ideas before I write.

S2: Writing will become easier if we can recall some related words and phrases before we write. It will be more useful if those words and phrases can be categorized.

Apart from students, the writing teacher also asserts that brainstorming is a good way to help students to prepare well before they start to write.

T1: With the help of brainstorming, students can activate their prior knowledge and broaden their minds relating to their writings. Besides, students can contribute information collaboratively. By sharing different opinions and generating new ideas before writing, students can be well prepared.

\subsubsection{Advantages of the While-Writing Stage}

The while-writing stage requires students to produce three drafts. About half of students think that three drafts can make their writings better.

S3: I think three drafts are better than only one draft. In the first draft, I mainly focus on the content, but there may be many mistakes in grammar, vocabulary and so on. In the second draft, I have a chance to solve those problems. In the third draft, I may find more appropriate words or phrases, which can make my writing better.

S4: I often make many mistakes in my writing. When I write three drafts, I can correct most of those mistakes step by step.

The writing teacher also thinks that three drafts of writing is beneficial, for it can save the teacher's time and energy to correct the final drafts and it can also help students to improve their writing proficiency gradually.

T2: Three drafts of writing can be very useful. If students write only one draft, their errors can be found out here and there in terms of vocabulary, grammar, and spelling, etc. So it often takes me plenty of time to correct all those errors each time. When students are asked to write three drafts, it will lessen my time and labor in correcting their final drafts, for they have made their writings better through iterative reviewing and redrafting. At the same time, students have more opportunities to improve their writings by means of three drafts, and thus they can $g$ enhance their writing abilities.

\subsubsection{Advantages of the Post-Writing Stage}

Most students think that the post-writing stage is very essential, in which peer review, teacher feedback and final 
publication are considered to be very significant.

\subsubsection{Peer Review}

About $70 \%$ of students think that peer review is beneficial, for it can provide immediate help and enhance collaborative learning.

S5: Peer review is more convenient than teacher feedback. So I prefer to discuss with my classmates when I have some troubles in my writing.

S6: When my classmates review my writing, they can often find out some mistakes which I can not notice because of my carelessness.

S7: I can also learn something from my classmates when I review their writings. For example, how they express their ideas, how they organize the paper, how they choose proper words and so on can give me some hints in my future writing.

\subsubsection{Teacher Feedback}

More than $60 \%$ of students think that in addition to peer review, teacher feedback can give them further suggestions and comments.

S8: I think teacher feedback is very necessary, particularly when my classmates and I have different opinions in my writing. After all, the authoritative teacher can give us some good suggestions.

S9: If my classmates think that my writing is very good, I will expect to get some reply from my teacher as well. If my teacher also praises my writing, I will feel extremely pleased.

The writing teacher points out that teacher feedback is very significant during the post-writing stage, for it can help students to notice their strong and weak points in English writings and thus help them to enhance their writing proficiency.

T3: Teacher feedback actually plays a key role during the post-writing stage. Without teacher feedback, students may not clearly know their merits or demerits in their writings. Therefore, apart from peer review, teacher feedback is very essential in process writing, especially when students cannot get enough help from their classmates. When I read through students'final drafts, I focus on the expression of ideas, the organization of the paper, the appropriation of words, and the use of artistic skills, etc. In addition to giving feedback to students' writings, I also give comments to peers' review. Moreover, each time I select some excellent writings to share in class, and I summarize some typical writing problems to discuss with students. By reminding students of their merits and demerits in their writings, I hope teacher feedback can be helpful to improve their writing abilities.

\subsubsection{Final Publication}

Nearly $60 \%$ of students think that final publication is necessary, for it can develop their motivation, acknowledge peers' effort and enhance cooperative learning.

S10: It is very exciting for me to go to the stage and talk about my writing, which gives me a chance to show myself and can surely increase my confidence.

S11: When my classmates present their writings in class which have been reviewed by me, I feel very happy. It seems that I am reading my own writing on the stage.

S12: My writing is not very good. I try to learn something from my classmates when they read their writings in class.

\section{Discussion}

The traditional way of teaching writing mainly focuses on the final and fixed product at the cost of writing process (Zamel, 1985), which can neither cater to students' needs nor satisfy teachers themselves. Different from the traditional way of teaching writing, process writing emphasizes multi-drafts and revisions (Liu \& Hansen, 2002), which can benefit both students and teachers. According to the results of questionnaires and semi-structured interviews, both junior English majors and their writing teachers at CWNU acknowledge advantages of process writing through its three stages: the pre-writing stage, the while-writing stage, and the post-writing stage.

It can be seen that process writing is beneficial in Chinese EFL classrooms in higher education. Firstly, with the help of brainstorming, students can be prepared well by sharing different information and generating new ideas under the given topic. Secondly, by means of three drafts of writing, students can have more chances to improve their writings from draft to draft, which can make their final writings as good as possible. Thirdly, 
during the post-writing stage, peer review, teacher feedback and final publication can encourage students' motivation, acknowledge their effort and improve the quality of their writings. Therefore, students can really benefit a lot from process writing by means of writing to learn in a dynamic and collaborative atmosphere. Apart from students, process writing can be beneficial to their writing teachers as well. First of all, it can greatly reduce teachers' time and workload to correct all kinds of mistakes for students. What's more, process writing can provide teachers chances to learn more about their students, which is helpful to enhance the communication between teachers and students.

However, apart from those advantages, some possible disadvantages of process writing need to be noticed. First of all, process writing may be considered as time-consuming in class, for it includes three stages with many activities involved. Therefore, it is suggested that some of the activities should be carried out after class, such as peer review, the second drafting and the third drafting. Secondly, peers' ability to comment the writing may be doubted sometimes. Therefore, a clear instruction of how to implement peer review should be given at the very beginning, and teachers need to provide timely help when students confront some difficulties in the process of writing. Thirdly, a few students may be reluctant to share their ideas in brainstorming or be unwilling to give negative comments in peer review. Therefore, those students need to be encouraged to express their ideas freely in a friendly learning environment.

\section{Conclusion}

This study investigates junior English majors and their teachers about how they perceive process writing at China West Normal University. Both students and teachers acknowledge the potential advantages of process writing during its three stages: the pre-writing stage (involving brainstorming), the while-writing stage (including three drafts of writing), and the post-writing stage (covering peer review, teacher feedback and final publication). Although this study mainly focuses on the perceptions of junior English majors and their teachers at CWNU, it is hoped that process writing can be beneficial to other Chinese EFL classrooms in higher education as well. As EFL classrooms may share some common features in English teaching, this study may also have some implications for teaching writing in other EFL countries.

\section{Acknowledgements}

This study is financed by Department of Education of Sichuan Province (Project No. 12SA135), Sichuan Center for Education Development Research (Project No. CJF012013), Nanchong City Federation of Social Sciences in Sichuan Province, and the Center for Translation and Research of Chinese Culture and Literature. I am also sincerely indebted to my supervisor, Dr. Christine C. M. Goh at National Institute of Education, Nanyang Technological University, Singapore, for her valuable guidance during my postgraduate study in Singapore and for her kindly encouragement in my further research.

\section{References}

Barr, M. (1983). The new orthodoxy about writing: Confusing process and pedagogy. Language Art, 60(7), 829-870.

Chandrasegaran, A. (2002). Intervening to help in the writing process. Singapore: SEAMEO Regional Language Centre.

Chew, P. G. L. (2006). Asian realities in language learning: The case of Singapore. CELEA Journal, 29(1), 3-11.

Ferris, D. R. (1997). The influence of teacher commentary on student revision. TESOL Quarterly, 31(2), 315-339. http://dx.doi.org/10.2307/3588049

Grabe, W., \& Kaplan, R. B. (1996). Theory and practice of writing. Essex: Addison Wesley Longman Limited.

Hu, G. W. (2005). Using peer review with Chinese ESL student writers. Language Teaching Research, 9(3), 321-342. http://dx.doi.org/10.1191/1362168805lr169oa

Hyland, K. (2003). Second language writing. Cambridge University Press. http://dx.doi.org/10.1017/CBO9780511667251

Jacobs, G. (1989). Miscorrection in peer feedback in writing class. RELC Journal, 20(1), 68-76. http://dx.doi.org/10.1177/003368828902000105

Jordan, R. R. (1997). English for academic purposes: A guide and resource book for teachers. Cambridge University Press. http://dx.doi.org/10.1017/CBO9780511733062

Liu, J., \& Hansen, J. G. (2002). Peer response in second language writing classrooms. Ann Arbor: The 
University of Michigan Press.

Mackey, A., \& Gass, S. M. (2005). Second language research: Methodology and design. Mahwah, New Jersey: Lawrence Erlbaum Associates, Inc.

Raimes, A. (1987). Exploring through writing: A process approach to ESL composition. New York: St. Martin's Press.

Richards, J. C. (2005). Communicative language teaching today. Singapore: SEAMEO Regional Language Centre.

Sommers, N. (1982). Responding to student writing. College Composition and Communication, 33(2), 148-156. http://dx.doi.org/10.2307/357622

Takagaki, T. (2003). The revision patterns and intentions in L1 and L2 by Japanese writers: A case study. TESL Canada Journal, 21(1), 22-38.

Taylor, S. J., \& Bogdan. R. (1998). Introduction to qualitative research methods: A guidebook and resource (3rd ed.). New York: John Wiley \& Sons, Inc.

Tompkins, G. (1990). Teaching and writing: Balancing process and product. Columbus, OH: Merrill Publishing Co.

White, R., \& Arndt, V. (1991). Process writing. London \& New York: Longman.

Zamel, V. (1983). The composing processes of advanced ESL students: Six case studies. TESOL Quarterly, 17(2), 165-187. http://dx.doi.org/10.2307/3586647

Zamel, V. (1985). Responding to student writing. TESOL Quarterly, 19(1), 79-101. http://dx.doi.org/10.2307/3586773

\section{Appendix A}

\section{Questionnaire}

Instructions:

This questionnaire aims to find out your perceptions about process writing. Please tick $(\sqrt{ })$ the activity (or activities) which can be beneficial to improve your writing proficiency compared with the traditional way of writing. There is no right or wrong answer. Thank you.

1) Brainstorming

2) Three drafts of writing

3) Peer review

4) Teacher feedback

5) Final publication

Notice: In order to deepen our understanding of your perceptions about process writing, there will be an interview to investigate the reason why you think the activity is beneficial. If you would like to take part in the interview, please write down your name and telephone number here. Thanks a lot.

Name:

Telephone number:

\section{Appendix B}

\section{Interview with Junior English Majors}

Instructions:

Thank you very much to take part in this interview. You have acknowledged advantages of process writing in the survey of questionnaires. Now I would like to know more about the reason why you think the activity can help you to improve your writing ability.

1) Could you tell me why brainstorming is useful?

2) Why do you like three drafts of writing?

3) Could you tell me the reason why peer review is helpful? 
4) Why do you like teacher feedback?

5) Why do you think final publication is beneficial?

\section{Appendix C}

\section{Interview with English Writing Teachers}

Instructions:

Thank you very much to participate in this interview. You have conducted process writing in your teaching, so could you tell me which activity you like best in terms of brainstorming, three drafts of writing, peer review, teacher feedback, or final publication? And could you tell me the reason why you think such an activity is beneficial in Chinese EFL classrooms in higher education? Thank you.

\section{Copyrights}

Copyright for this article is retained by the author(s), with first publication rights granted to the journal.

This is an open-access article distributed under the terms and conditions of the Creative Commons Attribution license (http://creativecommons.org/licenses/by/3.0/). 